\title{
ARTICLE
}

Chronic myeloproliferative neoplasms

\section{Autocrine Tnf signaling favors malignant cells in myelofibrosis in a Tnfr2-dependent fashion}

\author{
William L. Heaton ${ }^{1} \cdot$ Anna V. Senina ${ }^{1} \cdot$ Anthony D. Pomicter ${ }^{1} \cdot$ Mohamed E. Salama $^{2} \cdot$ Phillip M. Clair $^{1}$ • \\ Dongqing Yan ${ }^{1} \cdot$ Russell N. Bell ${ }^{1} \cdot$ Jeremy M. Gililland ${ }^{3} \cdot$ Josef T. Prchal ${ }^{4} \cdot$ Thomas O'Hare $^{1,4} \cdot$ Michael W. Deininger $^{1,4}$
}

Received: 22 January 2018 / Revised: 23 March 2018 / Accepted: 29 March 2018 / Published online: 18 April 2018

(c) The Author(s) 2018. This article is published with open access

\begin{abstract}
Tumor necrosis factor alpha (TNF) is increased in myelofibrosis (MF) and promotes survival of malignant over normal cells. The mechanisms altering TNF responsiveness in MF cells are unknown. We show that the proportion of marrow (BM) cells expressing TNF is increased in MF compared to controls, with the largest differential in primitive cells. Blockade of TNF receptor 2 (TNFR2), but not TNFR1, selectively inhibited colony formation by MF CD34 ${ }^{+}$and mouse JAK2 ${ }^{\mathrm{V} 617 \mathrm{~F}}$ progenitor cells. Microarray of mouse MPN revealed reduced expression of X-linked inhibitor of apoptosis (Xiap) and mitogenactivated protein kinase 8 (Mapk8) in $\mathrm{JAK} 2^{\mathrm{V} 617 \mathrm{~F}}$ relative to JAK2 ${ }^{\mathrm{WT}}$ cells, which were normalized by TNFR2 but not TNFR1 blockade. XIAP and MAPK8 were also reduced in MF CD34 ${ }^{+}$cells compared to normal $\mathrm{BM}$, and their ectopic expression induced apoptosis. Unlike XIAP, expression of cellular IAP (cIAP) protein was increased in MF CD34 ${ }^{+}$cells.

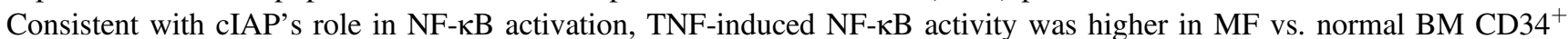
cells. This suggests that $\mathrm{JAK} 2^{\mathrm{V} 617 \mathrm{~F}}$ reprograms TNF response toward survival by downregulating XIAP and MAPK8 through TNFR2. Our results reveal an unexpected pro-apoptotic role for XIAP in MF and identify TNFR2 as a key mediator of TNF-induced clonal expansion.
\end{abstract}

\section{Introduction}

Myelofibrosis (MF) is a myeloproliferative neoplasm (MPN) characterized by bone marrow (BM) reticulin fibrosis, anemia, and splenomegaly due to extramedullary hematopoiesis. Constitutive activation of JAK/STAT signaling due to somatic mutations in Janus kinase 2 (JAK2), calreticulin (CALR) or the thrombopoietin receptor (MPL)

Electronic supplementary material The online version of this article (https://doi.org/10.1038/s41375-018-0131-z) contains supplementary material, which is available to authorized users.

Michael W. Deininger

michael.deininger@hci.utah.edu

1 Huntsman Cancer Institute, University of Utah, Salt Lake City, UT, USA

2 ARUP Laboratories, University of Utah, Salt Lake City, UT, USA

3 Department of Orthopaedics, University of Utah, Salt Lake City, UT, USA

4 Division of Hematology and Hematologic Malignancies, University of Utah, Salt Lake City, UT, USA is central to MF pathogenesis and endows neoplastic cells with a competitive advantage over their normal counterparts [1-6]. JAK2 inhibitors, such as ruxolitinib, reduce splenomegaly and symptom burden and may prolong survival in MF patients, but are not curative [7]. JAK/STAT signaling promotes generation of inflammatory cytokines such as tumor necrosis factor (TNF), which cause constitutional symptoms such as weight loss and fever [8]. We have shown that TNF stimulates myeloid colony formation by MF CD $34^{+}$cells but reduces colony formation by normal controls and that absence of TNF attenuates disease in mice with JAK2 ${ }^{\mathrm{V} 617 \mathrm{~F}}$-induced MPN [2].

The aging BM is characterized by inflammation, a bias toward myelomonocytic differentiation and somatic mutations in genes related to myeloid malignancies, including JAK2 [9-14]. This suggests that MPNs such as MF may arise through a process in which clones carrying JAK2 activating mutations are selected in the inflammatory environment, a concept supported by the steep increase of MPN incidence with age [15]. The fact that TNF mediates the proliferative advantage of MPN over normal cells suggests therapeutic utility for TNF antagonists. The TNF neutralizing agent etanercept improved symptoms in a pilot 
study of MF patients [16]. However, TNF inhibitors have not been developed as MF therapeutics, reflecting concerns about immunosuppression in an already immunocompromised patient population.

TNF signaling involves two distinct receptors, TNF receptor 1 (TNFR1) and TNF receptor 2 (TNFR2). TNFR1 expression is ubiquitous, while TNFR2 expression is largely confined to cells of hematopoietic origin. Only TNFR1 contains an intracellular death domain (DD) that is required for formation of a pro-apoptotic complex (Complex II) consisting of Fas-associated death domain (FADD), TNFR1-associated death domain (TRADD), receptorinteracting serine/threonine protein kinase 1 (RIPK1) and procaspase-8 [17]. Despite TNFR1's ability to form this pro-apoptotic complex, the initial signaling event following TNF engagement is the formation of a membrane bound complex (Complex I) where TRADD associates with TNFR-associated factor 2 (TRAF2), cellular inhibitor of apoptosis (cIAP) and poly-ubiquitinated RIPK1 leading to nuclear factor- $\kappa \mathrm{B}(\mathrm{NF}-\kappa \mathrm{B})$ activation. Subsequent formation of Complex II occurs after dissociation from TNFR1 and internalization to the cytoplasm [18]. Cell fate is dependent on factors that balance the NF- $\mathrm{KB}$ induction of inflammatory and survival signals with caspase-8dependent apoptosis. Important factors are cIAP-mediated stabilization of Complex I and expression of the long isoform of cellular FLICE (FADD-like IL-1 $\beta$-converting enzyme)-inhibitory protein (c-FLIP $\left.{ }_{\mathrm{L}}\right)$, an inactive caspase8 homolog that competes for binding to FADD, thereby maintaining Complex II in an inactive state [19, 20]. Since TNFR2 lacks the DD, it cannot associate with TRADD and FADD, however TNFR2 is able to bind TRAF2 and coordinate NF- $\mathrm{kB}$ signaling in association with cIAP [21].

The fact that TNF favors growth of MPN over normal cells suggests that JAK/STAT activation shifts TNF signaling outcomes to survival/proliferation, but it is unknown which differences in signaling between MPN and normal cells underlie the differential response to TNF. Here we show that blocking TNFR2 but not TNFR1 selectively inhibits MPN cells over normal controls and implicate Xlinked inhibitor of apoptosis (XIAP), cIAP and mitogenactivated protein kinase 8 (MAPK8) as key mediators of differential responses to TNF.

\section{Methods}

\section{Human samples}

Peripheral blood (PB) and BM samples were collected according to an IRB-approved protocol (\#45880), following informed consent. When isolating specific cell fractions, mononuclear cells (MNCs) were prepared with ficoll-paque
(GE Healthcare, Uppsala, Sweden) and positive selection with microbeads (Miltenyi Biotec, Bergisch Gladbach, Germany) was performed on an autoMACS Pro Separator (Miltenyi). Details of MF patient information and normal BM donors are provided in Supplemental Tables 1-2.

\section{Intracellular TNF and TNF receptor (TNFR) staining}

Leukocytes from MF $(n=5)$ or normal $\mathrm{BM}(n=10)$ samples were treated with $10 \mu \mathrm{g} / \mathrm{mL}$ brefeldin A (SigmaAldrich) and $100 \mathrm{ng} / \mathrm{mL}$ lipopolysaccharide (LPS; SigmaAldrich), where indicated. Human antibody panels were used to identify stem and progenitor cells as described [22] and mature populations were identified using standard markers. Stem and progenitor cell populations in Balb/c mice $(n=8)$ were identified as reported [23] except for the omission of Sca-1 (low expression in Balb/c mice; complete list of markers and antibodies is provided in the Supplemental Tables 3-6). Cells were stained for surface markers prior to incubation in a paraformaldehyde/saponin buffer (BD Bioscience, Franklin Lakes, NJ), then stained with TNF antibody (BD Bioscience). Samples were analyzed using a FACSCanto cytometer (BD Bioscience) and analyzed with FlowJo analysis software (Treestar, Ashland, OR). Graphs show mean/s.e.m.

\section{Clonogenic assays}

In murine samples, lineage depletion was performed with an autoMACS Pro Separator (Miltenyi Biotec), prior to sorting for $\mathrm{DAPI}^{-} \mathrm{Kit}^{+}$positive cells with a FACSAria Cell Sorter (BD). Human $\mathrm{CD} 34^{+}$cells $(\mathrm{MF}-\mathrm{n}=4, \mathrm{CB}-\mathrm{n}=3$ ) or $\mathrm{Lin}$ ${ }^{-} \mathrm{Kit}^{+}$mouse cells $(n=3)$ were treated in liquid culture with TNFR blocking antibodies (Supplemental Table 7) at $10 \mu \mathrm{g} /$ $\mathrm{mL}$ for $72 \mathrm{~h}$, then plated in MethoCult with continued antibody treatment. Liquid culture and colony assays were supplemented with SCF (human-50 ng/mL, murine-100 ng/ $\mathrm{mL}$ ) and IL-3 (human- $10 \mathrm{ng} / \mathrm{mL}$, murine- $50 \mathrm{ng} / \mathrm{mL}$ ). Inducible shRNA constructs were purchased from Cellecta (Mountain View, CA) in lentiviral vectors containing a GFP expression marker. $\mathrm{GFP}^{+}$cells were sorted 3 days post infection $(n=3)$, and treated $\pm 200 \mathrm{ng} / \mathrm{mL}$ doxycycline (Clontech Laboratories Inc., Mountain View, CA). Cells were maintained in liquid culture for $96 \mathrm{~h}$, transferred to clonogenic assays as described above, with colonies scored after 10-14 days. Graphs show mean/s.e.m.

\section{Microarray analysis}

$\mathrm{BM}$ cells were harvested from 3 to 4 mice for each experiment, cultured for $16 \mathrm{~h} \pm$ TNFR1 or TNFR2 BA $(10 \mu \mathrm{g} / \mathrm{mL})$. After treatment, $\mathrm{Lin}^{-} \mathrm{Kit}^{+}$cells were isolated as described above and further subdivided into $\mathrm{GFP}^{+}$and $\mathrm{GFP}^{-}$cells for 


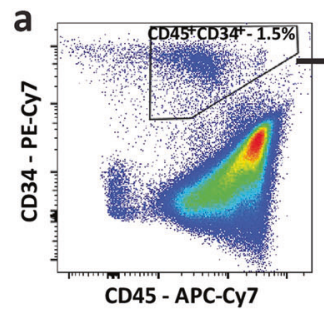

b
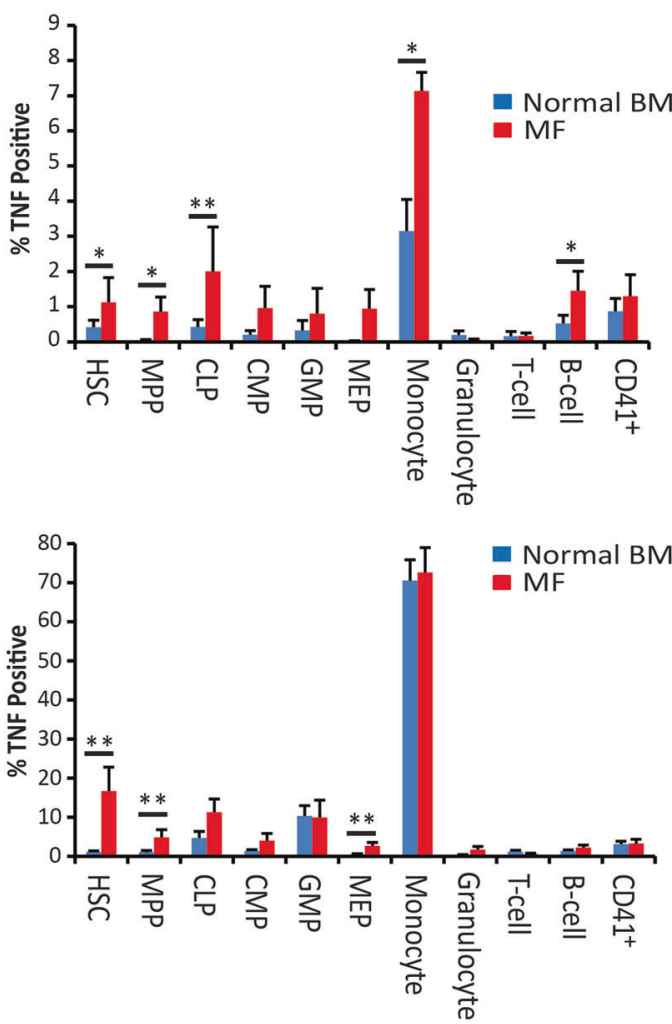

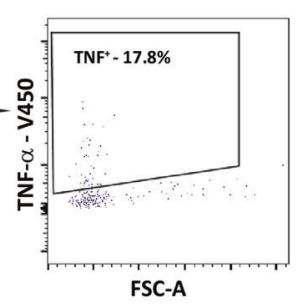

C
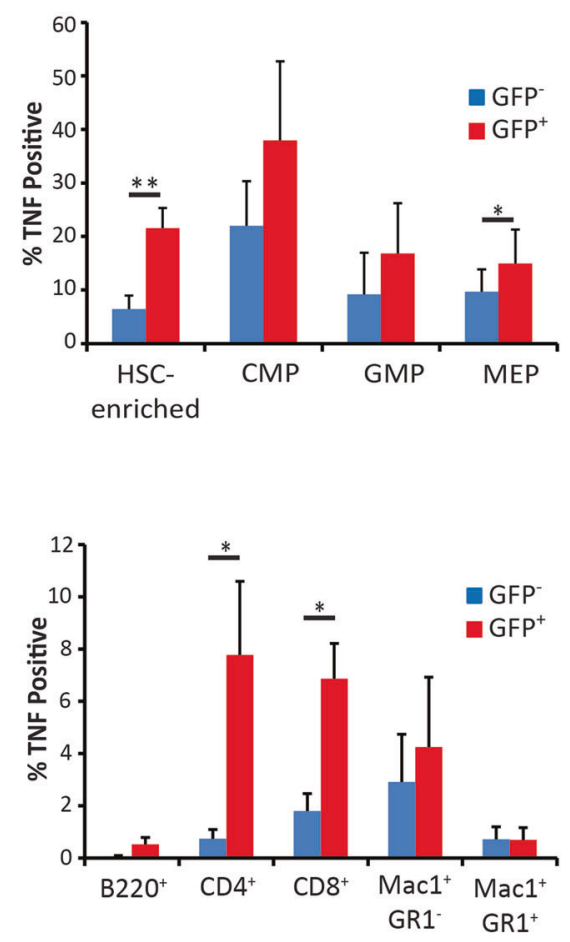

Fig. 1 TNF expression is higher in HSCs from MF patients compared to normal $\mathrm{BM}$ and in cells from $\mathrm{JAK} 2^{\mathrm{V} 617 \mathrm{~F}+}$ compared to JAK2 $2^{\mathrm{V} 617 \mathrm{~F}-}$ mice. a Primary cells were immunophenotyped with surface markers and intracellular TNF staining was performed to identify expression in hematopoietic lineages, with HSCs defined as $\mathrm{CD} 45^{+} \mathrm{CD} 34^{+} \mathrm{CD} 38$

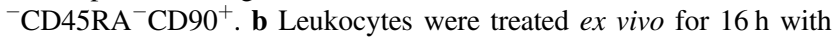
the protein transport inhibitor brefeldin A $(10 \mu \mathrm{g} / \mathrm{mL})$. The percentage of $\mathrm{TNF}^{+}$cells was higher in MF patients $(n=5 ; \mathrm{PB}=4, \mathrm{BM}=1)$ compared to normal BM $(n=10)$ in HSCs, MPPs, CLPs, monocytes and B cells. c Addition of LPS (100 ng/mL) increased the differences in TNF expression between MF specimens $(n=5 ; \mathrm{PB}=4, \mathrm{BM}=1)$

a total of six distinct groups. Three independent experiments were performed and RNA was isolated using RNeasy Micro Kit (Qiagen, Germantown, MD). RNA was further purified using Clean \& Concentrator columns (Zymo Research, Irvine, CA), cDNA was prepared with the Ovation Pico WTA System V2 (NuGEN, San Carlos, CA) and labeled with the Encore Biotin Module (NuGEN). The cDNA target samples were hybridized to an Affymetrix Mouse Expression 4302.0 array (Thermo Fisher Scientific). Image processing was performed using Affymetrix Command Console and normal BM $(n=10)$ for HSCs, MPPs and MEPs while expression in monocytes was equivalent. d, e Similar experiments were performed with $\mathrm{BM}$ cells isolated from JAK $2^{\mathrm{V} 617 \mathrm{~F}}$ MPN mice $(n=8)$, including brefeldin A treatment. d TNF expression was significantly higher in JAK2 ${ }^{\mathrm{V} 617 \mathrm{~F}+} \mathrm{Lin}^{-} \mathrm{Kit}^{+} \mathrm{CD} 48^{-} \mathrm{CD} 150^{+}$HSC-enriched cells and $\mathrm{Lin}^{-} \mathrm{Kit}$ ${ }^{+} \mathrm{CD} 34^{-} \mathrm{Fc} \gamma \mathrm{RII} / \mathrm{RIII}{ }^{\mathrm{Lo}}$ MEPs. e In the mature compartments, JAK2 ${ }^{\mathrm{V} 617 \mathrm{~F}+}$ T-cells $\left(\mathrm{CD}^{+}\right.$and $\left.\mathrm{CD}^{+}\right)$expressed higher TNF than JAK2 $2^{\mathrm{V} 617 \mathrm{~F}-} \mathrm{T}$-cells, while expression in B cells $\left(\mathrm{B} 220^{+}\right)$and myeloid cells $\left(\mathrm{Mac}-1^{+} / \mathrm{GR}-1^{-}\right.$and $\left.\mathrm{Mac}-1^{+} / \mathrm{GR}-1^{+}\right)$was similar. $* P<0.05$, $* * P<0.005$

(AGCC) v.3.1.1 software (Thermo Fisher Scientific) and expression analysis was performed using Affymetrix Expression Console build 1.4.1.46 (Thermo Fisher Scientific). Data have been uploaded to Gene Expression Omnibus (accession number GSE104792).

\section{Statistical analysis}

Significance of individual comparisons was determined by Student's $t$-test with paired comparisons for murine samples 
$\left(\mathrm{JAK}^{\mathrm{V} 617 \mathrm{~F}+}\right.$ and $\mathrm{JAK} 2^{\mathrm{V} 617 \mathrm{~F}-}$ cells from individual mice) and unpaired comparisons between human MF samples relative to normal controls (with test for variance). Twotailed tests were used for all comparisons except for intracellular TNF expression (one-tailed) where the distribution was limited by zero values. A two-way ANOVA was used for comparison of the NFKB time-course experiment.

\section{Results}

\section{TNF expression is increased in MPN cells from multiple hematopoietic cell compartments}

To determine the cellular origin of TNF, we assessed expression by FACS in BM or blood of MF patients compared to normal controls (Fig. 1a). To increase intracellular TNF, allowing detection at the single-cell level, cells were treated with brefeldin A $(10 \mu \mathrm{g} / \mathrm{mL})[24,25]$. The percentage of $\mathrm{TNF}^{+}$cells was increased in hematopoietic stem cells (HSCs), multipotent progenitor cells (MPPs), common lymphoid progenitor cells (CLPs), monocytes and mature B cells (Fig. 1b upper panel). To determine whether cell populations were differentially sensitive to inflammatory stimuli, cells were treated with LPS $(100 \mathrm{pg} / \mathrm{mL})$. TNF expression in monocytes from MF patients $\left(72.5 \% \mathrm{TNF}^{+}\right)$ and normal individuals $\left(70.5 \% \mathrm{TNF}^{+}\right)$was comparable. In contrast, LPS-induced TNF expression in primitive populations was elevated in MF relative to normal controls, with the largest differential in $\mathrm{HSCs}\left(16.7 \%\right.$ vs. $\left.1.1 \% \mathrm{TNF}^{+}\right)$and significant differences in MPPs and MEPs (Fig. 1b lower panel). Since the average age of the control population used in this study was significantly lower than the MF population (40.0 vs. 59.8 years old, $P<0.001$ ), we also stratified normal controls based on age ( $<50$ vs. $>50$ years old) and compared TNF expression. We found no difference in any of the populations, except for the LPS-stimulated granulocytes $(P<0.05)$, although the absolute expression was extremely low in this populations $(<50=0.1 \%$ vs. $>50=$ $0.7 \% \mathrm{TNF}^{+}$; Supplemental Figure 1). Analogous experiments were performed on BM from Balb/c mice with MPN induced by transplantation of donor cells transduced with $\mathrm{JAK} 2^{\mathrm{V} 617 \mathrm{~F}}$, where $\mathrm{JAK} 2^{\mathrm{V} 617 \mathrm{~F}}$ cells are identified by GFP expression [26, 27]. TNF expression was generally higher in JAK2 ${ }^{\mathrm{V} 617 \mathrm{~F}}$ cells, with the largest difference in the HSCenriched population $\left(21.5 \%\right.$ vs. $6.4 \% \mathrm{TNF}^{+}$cells; Fig. 1c upper panel), irrespective of LPS stimulation. In mature populations, the largest difference in TNF expression between $\mathrm{JAK} 2^{\mathrm{V} 617 \mathrm{~F}+}$ and $\mathrm{JAK} 2^{\mathrm{V} 617 \mathrm{~F}-}$ cells was in $\mathrm{T}$ cells, while expression in the mature myeloid lineages $\left(\mathrm{Mac1}^{+}\right.$ and/or GR $1^{+}$) was comparable (Fig. 1c lower panel). These results indicate that the proportion of TNF expressing cells is consistently higher in MF vs. normal controls, particularly in less differentiated cell types. Furthermore, $\mathrm{JAK} 2^{\mathrm{V} 617 \mathrm{~F}}$ is sufficient to induce these differences in TNF expression.

\section{Treatment with pan-TNF inhibitors does not reduce disease burden in murine MPN}

To test the effects of TNF neutralization in vivo, we used two TNF inhibitors in a retroviral mouse model of $\mathrm{JAK} 2^{\mathrm{V} 617 \mathrm{~F}}$-induced MPN. Etanercept is a soluble TNFR2 decoy receptor that binds human or mouse TNF, and has shown efficacy in mouse models of rheumatoid arthritis (RA) [28]. CNTO5048 is a modified version of the TNFneutralizing antibody infliximab with an altered variable region that increases its affinity for mouse TNF [29]. Both agents are used to treat RA and other autoimmune disorders [30]. We confirmed the activity of each of these agents against mouse TNF in an assay of TNF-mediated cytotoxicity (L929 cells; Supplemental Figure 2a, b) [31]. In successive studies with etanercept and CNTO5048, mice with established MPN were treated for 8-12 weeks with dosing schedules reported to be effective in murine models of RA [28, 32]. Neutralization of soluble TNF in serum of mice was confirmed with the L929 cytotoxicity assay (Supplemental Figure 2c, d). No significant differences in white blood cell counts, hematocrit, $\mathrm{GFP}^{+}$cells (Supplemental Figure 2e-j) or spleen weights (Supplemental Figure $2 \mathrm{k}, \mathrm{l})$ were observed between treatment groups. These results are consistent with the modest effects observed with etanercept in MF that showed hematologic improvement in $20 \%$ of patients [16]. Since the TNF neutralizing agents failed to inhibit disease, we hypothesized that differential signaling from TNFR1 and/or TNFR2 underlies the competitive advantage of MPN cells.

\section{TNFR2 but not TNFR1 selectively suppresses myeloid colony formation by MPN progenitor cells}

To identify the mechanistic basis for the differential effects of TNF on MF vs. normal cells, we quantified TNF receptor expression in primitive (Supplemental Figure 3a) and mature (Supplemental Figure 3b) hematopoietic cells from human MF vs. normal BM and JAK2 $2^{\mathrm{V} 617 \mathrm{~F}+}$ vs. JAK2 ${ }^{\mathrm{V} 617 \mathrm{~F}-}$ cells from MPN mice (Supplemental Figure 3c). No significant differences were observed, suggesting that the differential effects of TNF on MPN vs. normal cells are due to modulation of downstream signaling events. To determine the contribution of TNFR1 and TNFR2-mediated effects on MPN clonal dominance, we used receptor blocking antibodies (BAs) to inhibit each receptor. The specificity of all BAs was confirmed using ELISA and L929 cytotoxicity assays (Supplemental Figure 4a-d). CD34 ${ }^{+}$cells from MF samples, normal BM or cord blood (CB) were cultured for 

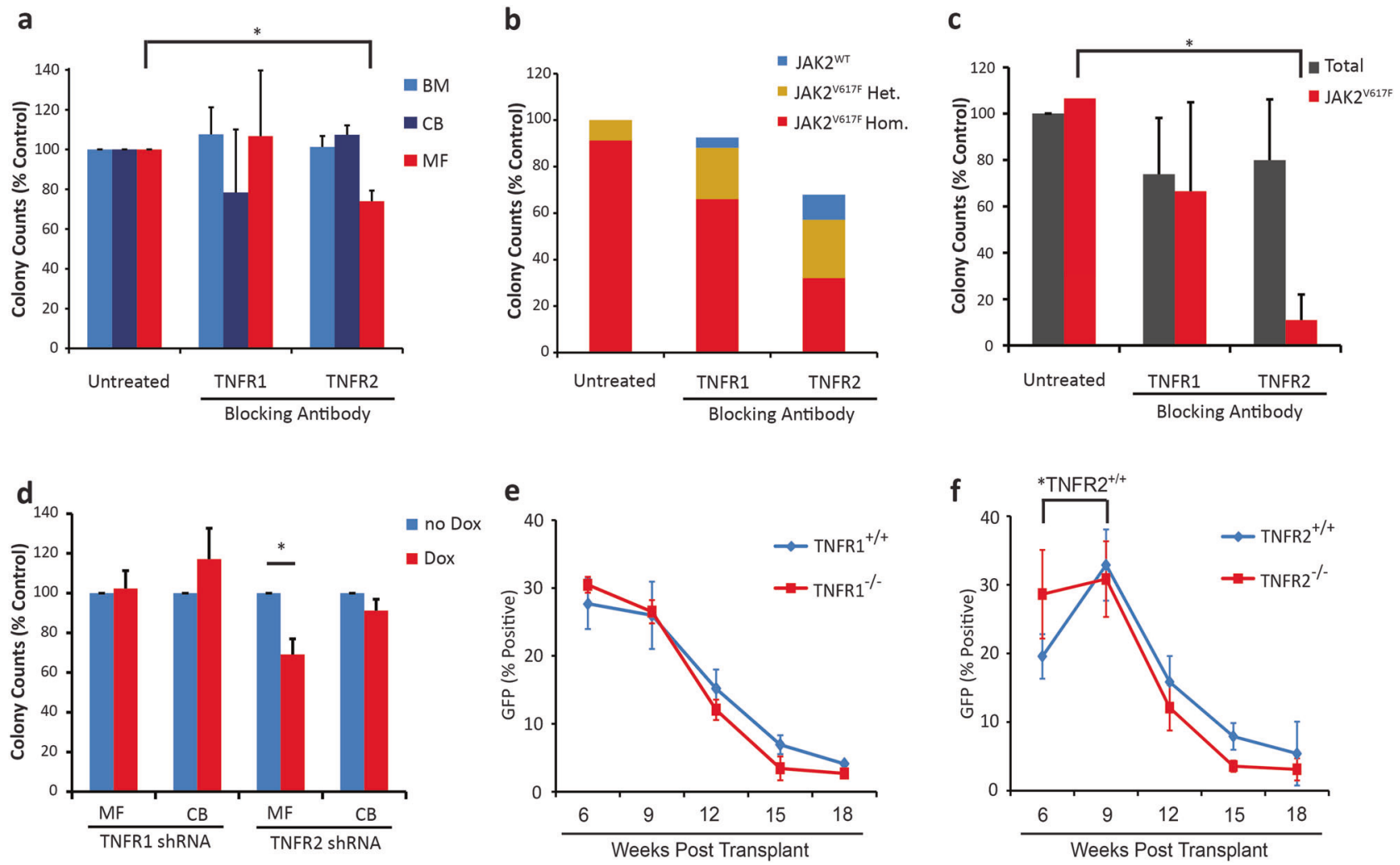

Fig. 2 Blocking TNFR2 selectively inhibits colony formation by MF vs. normal $\mathrm{BM} \mathrm{CD} 34^{+}$cells and mouse $\mathrm{JAK} 2^{\mathrm{V} 617 \mathrm{~F}+}$ compared to $\mathrm{JAK} 2{ }^{\mathrm{V} 617 \mathrm{~F}-}$ progenitor cells. a Human $\mathrm{CD} 34^{+}$cells from MF blood $(n$ $=4)$, normal BM $(n=3)$ or CB $(n=3)$ were treated with TNFR BAs at $10 \mu \mathrm{g} / \mathrm{mL}$ for $72 \mathrm{~h}$ in liquid culture, then plated in clonogenic assays with continued treatment. TNFR2 inhibition reduced colony numbers in MF samples without affecting normal BM or CB control samples. b In MF samples, the JAK2 genotype was analyzed for each colony. Of the four samples tested, three were found to have $100 \% \mathrm{JAK} 2^{\mathrm{V} 617 \mathrm{~F}}$ allele burden in all conditions tested, while one sample with a mixed $\mathrm{JAK} 2$ genotype had a reduction in $\mathrm{JAK} 2^{\mathrm{V} 617 \mathrm{~F}+}$ colonies and increase in JAK2 ${ }^{\text {WT }}$ colonies with TNFR2 inhibition and to a lesser degree with TNFR1 inhibition. $\mathbf{c} \mathrm{Lin}^{-} \mathrm{Kit}^{+} \mathrm{BM}$ cells from MPN mice $(n=3)$ were treated in liquid culture with TNFR BAs at $10 \mu \mathrm{g} / \mathrm{mL}$ for $72 \mathrm{~h}$, then plated in clonogenic assays with continued treatment. Colonies were enumerated after 10 days and isolated colonies genotyped for

$72 \mathrm{~h} \pm$ TNFR 1 or TNFR2 BAs $(10 \mu \mathrm{g} / \mathrm{mL})$, then transferred to semisolid medium with continued treatment. Blocking TNFR1 did not significantly change granulocytemacrophage (GM) colony numbers for $\mathrm{MF}, \mathrm{BM}$, or $\mathrm{CB}$ samples, while TNFR2 block consistently reduced MF colonies by $25-30 \%$, with no effect on BM or CB (Fig. 2a; colony counts provided in Supplemental Figure 5a-c). Single colonies were genotyped for JAK2 by BsaXI digestion (Supplemental Figure 6a). The vast majority of samples were homogenous for JAK2 ${ }^{\mathrm{V} 617 \mathrm{~F}}$ colonies. In one MF patient sample (from a patient with a JAK2 $2^{\mathrm{V} 617 \mathrm{~F}}$ allele burden of $\sim 85 \%$ ) with a mixture of JAK2 $2^{\mathrm{V} 617 \mathrm{~F}}$ and JAK2 $2^{\mathrm{WT}}$ colonies, blocking TNFR2 selected for JAK2 ${ }^{\mathrm{WT}}$ over
JAK2 status by analyzing GFP expression. TNFR2 inhibition selectively reduced colony formation of JAK2 ${ }^{\mathrm{V} 617 \mathrm{~F}+}$ cells without affecting total colony numbers, while TNFR1 inhibition had no effect. d MF ( $n$ $=4)$ and $\mathrm{CB}(n=4) \mathrm{CD}_{4} 4^{+}$cells were infected with doxycyclineinducible TNFR shRNAs, in liquid culture $\pm 200 \mathrm{ng} / \mathrm{mL}$ doxycycline for $96 \mathrm{~h}$ and then plated in clonogenic assays with continued treatment. Induction of the TNFR2 shRNAs reduced colony formation in MF samples without affecting normal controls, while induction with a TNFR1 shRNA had no effect. e, f BM cells from 5-FU-treated CD45.1 and e TNFR $1^{-1-}$ or f TNFR2 ${ }^{-l-}$ CD45.2 mice were infected with MSCV-IRES-JAK2 ${ }^{\mathrm{V} 617 \mathrm{~F}}$-GFP retrovirus. Equal numbers of wild type and null $\mathrm{GFP}^{+}$cells were injected into lethally irradiated $\mathrm{TNFR}^{+/+}$ recipients ( $n=8$ per group). TNFR2 ${ }^{+/+} \mathrm{GFP}^{+}$cells increased over $\mathrm{TNFR}^{-l-} \mathrm{GFP}^{+}$cells, while TNFR $1^{+/+} \mathrm{GFP}^{+}$cells remained at the same level as TNFR1 $1^{-1-}$ cells. However, $\mathrm{GFP}^{+}$engraftment was not maintained. $* P<0.05$

JAK2 ${ }^{\mathrm{V} 617 \mathrm{~F}}$ colonies (Fig. 2b). We next tested the effects of TNFR BAs on $\mathrm{Lin}^{-} \mathrm{Kit}^{+} \mathrm{BM}$ cells from mice with $\mathrm{JAK} 2{ }^{\mathrm{V} 617 \mathrm{~F}}$ MPN, using the same experimental design. After enumeration, 20-25 single GM colonies were genotyped using a FACS-based assay measuring GFP (Supplemental Figure $6 \mathrm{~b}, \mathrm{c})$. Both BAs mildly reduced total colony numbers. While the TNFR1 BA reduced $\mathrm{JAK} 2^{\mathrm{V} 617 \mathrm{~F}+}$ and JAK2 $2^{\mathrm{V} 617 \mathrm{~F}-}$ colonies to a similar degree, the TNFR2 blocking antibody selectively reduced $\mathrm{JAK} 2^{\mathrm{V} 617 \mathrm{~F}+}$ colonies (Fig. 2c). For validation, human $\mathrm{MF}$ and $\mathrm{CB} \mathrm{CD} 34^{+}$cells were infected with doxycycline-inducible shRNAs targeting TNFR1 or TNFR2 (Supplemental Table 8). Effective TNFR1/2 knockdown was confirmed in SET-2 cells 


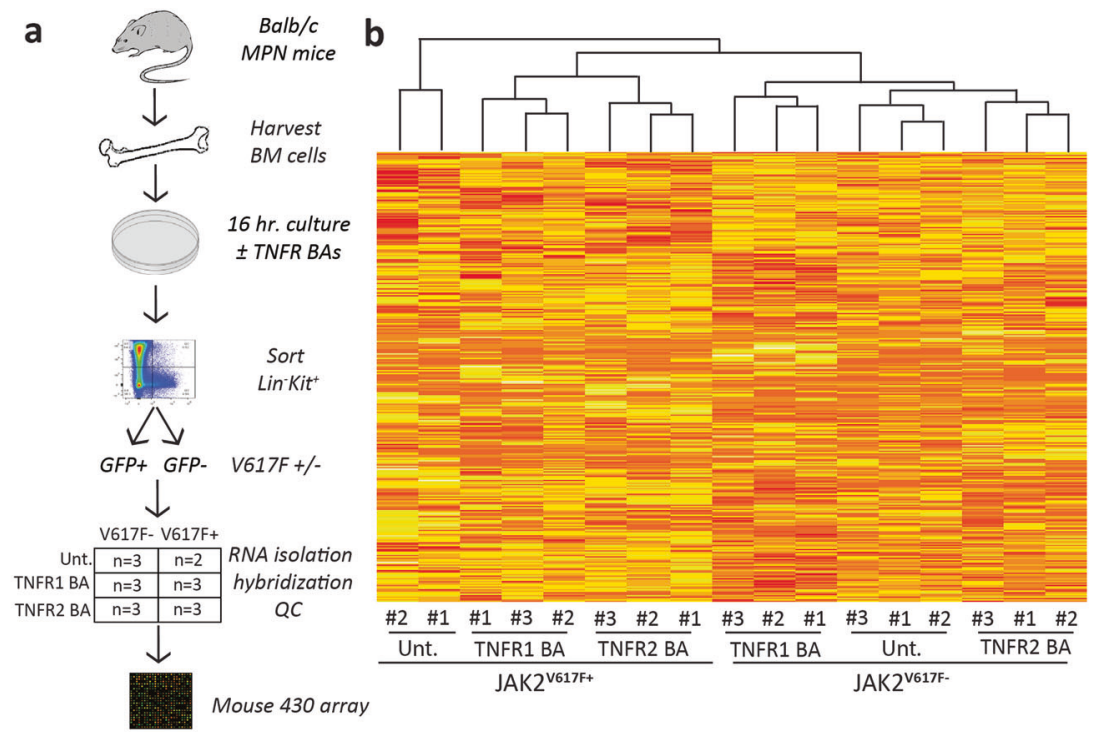

C Microarray analysis criteria - all p-value and Log2 $\mathrm{FC}$ comparisons relative to JAK2 ${ }^{\mathrm{V} 617 \mathrm{~F}-}$ (untreated)

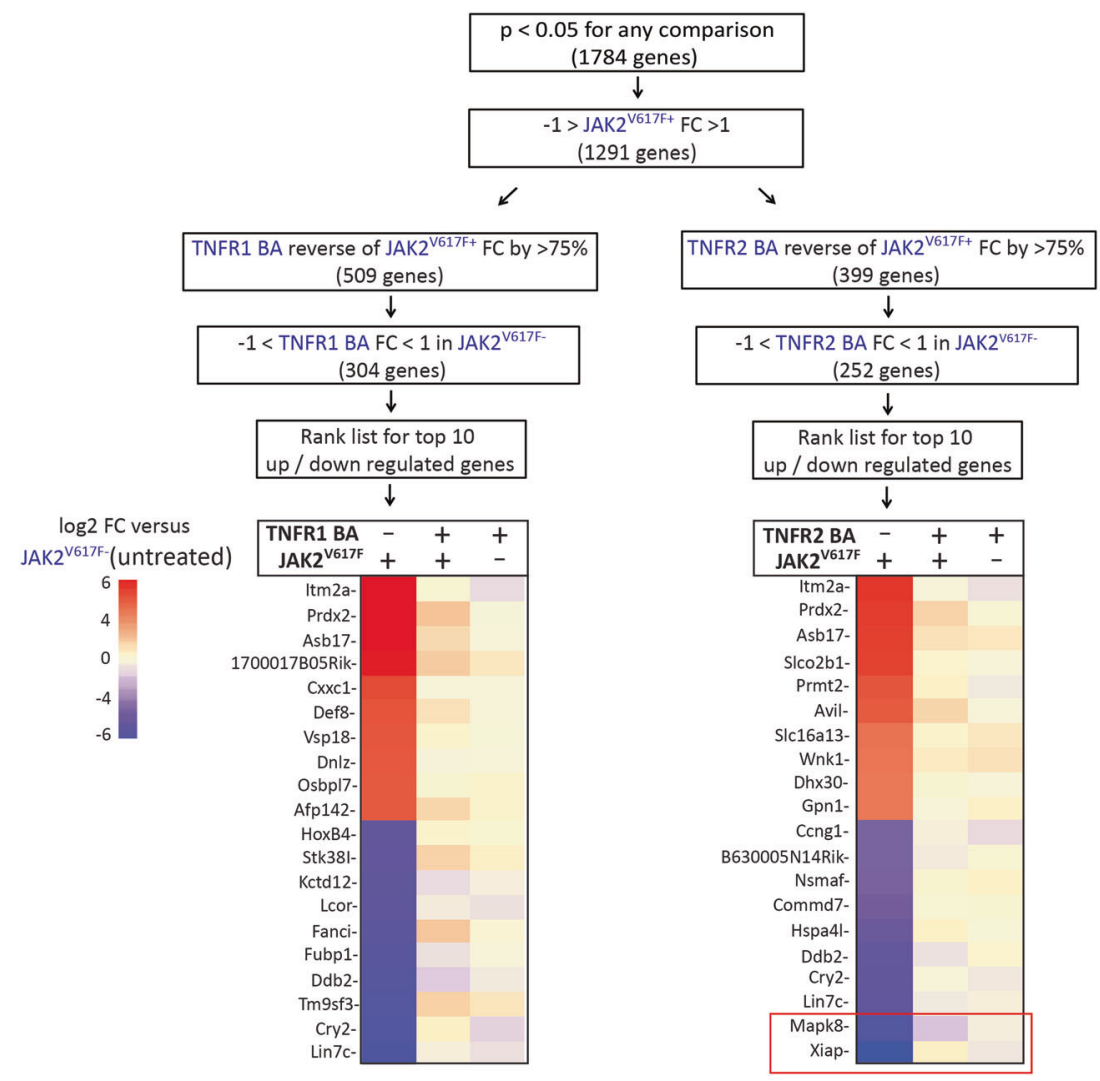

(Supplemental Figure 7a, b). Cells were cultured in cytokine containing media (SCF and IL-3, no exogenous TNF) \pm doxycycline prior to plating in colony assays with continued treatment. Knockdown of TNFR2 reduced colony formation by MF cells to a similar degree as seen with the
TNFR2 BA ( 30\%) with no effect on CB-derived colonies, while knockdown of TNFR1 had no effect (Fig. 2d). Altogether these results suggest that the differential effects of TNF on MPN vs. normal progenitor cells are mediated by TNFR 2 and that selective inhibition of TNFR 2 may 
Fig. 3 Expression of Xiap and Mapk8 is downregulated in JAK2 $2^{\mathrm{V} 617 \mathrm{~F}}$ relative to $\mathrm{JAK} 2^{\mathrm{V} 617 \mathrm{~F}-}$ cells, but this differential is abolished by TNFR2 inhibition. a BM cells from mice with $\mathrm{JAK} 2^{\mathrm{V} 617 \mathrm{~F}}$-induced MPN was cultured for $16 \mathrm{~h} \pm$ TNFR BAs $(10 \mu \mathrm{g} / \mathrm{mL})$. Cells were then sorted for $\mathrm{Lin}^{-} \mathrm{Kit}^{+}$expression, then subdivided based on GFP, resulting in six groups. Three independent experiments were performed. RNA was extracted for all 18 samples and subjected to microarray analysis using Affymetrix mouse 4302.0 arrays. One sample, Untreated-JAK2 $2^{\mathrm{V} 617 \mathrm{~F}+}$ replicate \#3 failed quality standards and was removed from further analysis. $\mathbf{b}$ Unsupervised clustering of the remaining 17 samples grouped all samples according to genotype $\left(\mathrm{JAK} 2^{\mathrm{V} 617 \mathrm{~F}}\right.$ ) and treatment. c Fold change $(\mathrm{FC})$ and $P$-values were generated for each condition relative to the JAK2 $2^{\mathrm{V} 617 \mathrm{~F}-}$ (Untreated) group. Sequential filters were applied to identify genes whose expression is dysregulated in $\mathrm{JAK} 2^{\mathrm{V} 617 \mathrm{~F}+}$ cells and restored with TNFR BA treatment. The set was limited to genes that had a $P$-value of $<0.05$ when compared between any two treatment groups. Then genes were limited to those that had a FC $>|1|$ in $J A K 22^{\mathrm{V} 617 \mathrm{~F}+}$ relative to $\mathrm{JAK} 2^{\mathrm{V} 617 \mathrm{~F}-}$ cells. Genes were then subdivided into those whose expression was reversed with either TNFR1 or TNFR2 BA in $\mathrm{JAK} 2^{\mathrm{V} 617 \mathrm{~F}+}$ toward JAK2 $2^{\mathrm{V} 617 \mathrm{~F}-}$ by $\geq 75 \%$. To further identify those that were selectively regulated in JAK2 $2^{\mathrm{V} 617 \mathrm{~F}+}$ cells, those with a FC $>1$ 1 I in JAK2 $2^{\mathrm{V} 617 \mathrm{~F}-}$ cells were eliminated. For each of these gene sets we ranked the top 10 up- or downregulated genes. Xiap and Mapk8 were the two top differentially expressed genes between $\mathrm{JAK} 2^{\mathrm{V} 617 \mathrm{~F}+}$ and JAK2 $2^{\mathrm{V} 617 \mathrm{~F}-}$ whose expression was normalized with TNFR2 BA treatment but not TNFR1 BA treatment.

reverse the clonal dominance of MPN cells. To test this, we performed a competitive repopulation assay with BM cells from $\mathrm{TNFR}^{+/+}$(CD45.1_C57BL/6) and $\mathrm{TNFR}^{-1-}$ (CD45.2_C57BL/6) mice. Analogous experiments were done using $\mathrm{TNFR}^{+/+}$vs. TNFR $1^{-/-}$donors. Engraftment of $\mathrm{GFP}^{+}$cells was monitored over time for $\mathrm{TNFR}^{+/+}$and $\mathrm{TNFR}^{-/-}$compartments with CD45.1 and CD45.2 specific antibodies (Supplemental Table 9). While the proportion of $\mathrm{TNFR}^{+/+}$and $\mathrm{TNFR}^{-/-}$cells within the $\mathrm{GFP}^{+}$population remained constant (Fig. 2e), JAK2 ${ }^{\mathrm{V} 617 \mathrm{~F}}$ expressing TNFR2 $+/+$ outcompeted TNFR2 $2^{-/-}$cells (Fig. 2f). However, engraftment of $\mathrm{GFP}^{+}$cells was transient and eventually $\mathrm{JAK} 2^{\mathrm{V} 617 \mathrm{~F}+}$ cells were lost irrespective of genotype, precluding further analysis.

\section{TNFR1 or TNFR2 inhibition partially reverses gene expression differences between $\mathrm{JAK} 2^{\mathrm{V} 617 \mathrm{~F}+}$ and JAK2 ${ }^{\mathrm{V} 617 \mathrm{~F}-}$ cells}

To identify the differences in TNF-induced signaling between $\mathrm{JAK} 2^{\mathrm{V} 617 \mathrm{~F}+}$ and $\mathrm{JAK} 2^{\mathrm{V} 617 \mathrm{~F}-}$ cells, we cultured $\mathrm{BM}$ cells from Balb/c mice with established JAK2 $2^{\mathrm{V} 617 \mathrm{~F}_{-}}$ induced MPN in media containing SCF and IL-3, \pm murine TNFR1 or TNFR2 BA in three independent experiments (Fig. 3a). $\mathrm{Lin}^{-} \mathrm{Kit}^{+}$cells were sorted into $\mathrm{GFP}^{+}$and $\mathrm{GFP}^{-}$ subsets and subjected to gene expression profiling. All but one sample (untreated-JAK2 $2^{\mathrm{V} 617 \mathrm{~F}+}$ replicate \#3, which was excluded) passed quality thresholds. Unsupervised hierarchical clustering grouped samples according to genotype (JAK2 $2^{\mathrm{V} 617 \mathrm{~F}+}$ vs. JAK2 $2^{\mathrm{V} 617 \mathrm{~F}-}$ ) and treatment (Fig. 3b). We hypothesized that genes critical to TNFR2's distinct effects would be differentially expressed in JAK2 $2^{\mathrm{V} 617 \mathrm{~F}+}$ vs. JAK $2^{\mathrm{V} 617 \mathrm{~F}-}$ cells and that blocking TNFR2 should reverse this difference. In addition, we considered genes regulated by TNFR2 in $\mathrm{JAK} 2^{\mathrm{V} 617 \mathrm{~F}+}$ cells with minimal effects in $\mathrm{JAK} 2^{\mathrm{V} 617 \mathrm{~F}-}$ cells as the highest priority and applied sequential filters to identify genes meeting these criteria for TNFR2 and TNFR1, respectively (Fig. 3c). Evaluation of the top 10 up- and downregulated genes, based on foldchange between JAK $2^{\mathrm{V} 617 \mathrm{~F}+}$ vs. JAK $2^{\mathrm{V} 617 \mathrm{~F}-}$ cells, showed that expression of the genes with the highest degree of upregulation (Itm $2 a ; \operatorname{Prd} 2 x 2 ; A s b 17)$ was reversed by either TNFR1 or TNFR2 block, while the two genes with the highest downregulation, Xiap and Mapk8 (Jnkl), were selectively reversed by TNFR2 but not TNFR1 block (Fig. 3c). We therefore focused on Xiap and Mapk8, as genes potentially mediating the differential effects of TNF signaling in $\mathrm{JAK} 2^{\mathrm{V} 617 \mathrm{~F}+}$ vs. JAK2 $2^{\mathrm{V} 617 \mathrm{~F}-}$ cells. While it is conceivable that other differentially expressed genes such as $\operatorname{Prd} x 2$ are also disease relevant, they were not investigated in the current study since they were not differentially regulated by TNFR2 over TNFR1.

To validate the microarray results, we analyzed by qPCR Xiap and Mapk8 expression in $\mathrm{Lin}^{-} \mathrm{Kit}^{+}$cells from an independent group of MPN mice $(n=3)$ and in MF patients and normal BM controls (primer sequences are provided in Supplemental Table 10). Expression of Xiap and Mapk8 was consistently lower in $\mathrm{JAK} 2^{\mathrm{V} 617 \mathrm{~F}+}$ compared to $\mathrm{JAK} 2^{\mathrm{V} 617 \mathrm{~F}-}$ murine cells and in MF cells compared to normal BM (Fig. 4a, b). MAPK8 has been implicated as a necessary component of TNF-mediated apoptosis [33], predicting that reduced expression would have an antiapoptotic effect. Although XIAP inhibits caspase activity, low expression of XIAP is permissive for stabilization of the related family member cIAP. IAPs are known to regulate each other's expression through their E3 ubiquitin ligase activity [34] and Xiap null mice show markedly increased cIAP protein [35]. Since cIAP is required for TNF-dependent NF- $\mathrm{B}$ signaling [36], we hypothesized that the growth advantage of MPN cells exposed to TNF could be mediated through an increase in cIAP protein levels. We evaluated cIAP expression in $\mathrm{CD}_{3}{ }^{+}$cells from MF samples and normal BM using immunofluorescence and found that cIAP expression was higher in MF samples relative to normal BM (Fig. 4c). Concordantly, cIAP staining was increased in $\mathrm{BM}$ cores from $\mathrm{MF}$ patients relative to normal controls (Fig. 4d). To validate the inverse relationship between XIAP and cIAP, we overexpressed XIAP in CD34 + cells from MF patient samples and measured cIAP expression. Overexpression of XIAP reduced cIAP levels relative to vector control (Fig. $4 \mathrm{e}$ ). 
Fig. 4 XIAP and MAPK8 mRNA expression is downregulated in mouse $\mathrm{JAK} 2^{\mathrm{V} 617 \mathrm{~F}+}$ cells and MF cells. a Xiap and Mapk8 mRNA expression was measured by qPCR, using glyceraldehyde 3phosphate dehydrogenase (Gapdh) as a control gene, in $\mathrm{Lin}^{-} \mathrm{Kit}^{+}$cells from mice with $\mathrm{JAK} 2^{\mathrm{V} 617 \mathrm{~F}}$-induced MPN $(n=$ 3). Xiap expression was significantly lower and Mapk8 expression trended lower $(p=$ $0.087)$ in JAK2 ${ }^{\mathrm{V} 617 \mathrm{~F}}$ cells. b $X I A P$ and $M A P K 8$ expression was measured by qPCR, using $\beta$-glucuronidase $(G U S)$ as a control gene, in MF $(n=5)$ and normal BM CD $34^{+}$cells $(n=$

$3)$. Expression of both genes was significantly lower in MF. c Immunofluorescent images of $\mathrm{CD}_{3}{ }^{+}$cells stained with a cIAP1/2 antibody. Fluorescence intensity was higher in MF ( $n=$ 4) cells compared to normal $\mathrm{BM}$ $(n=3)$. d Core BM biopsy sections from normal controls $(n$ $=5), \mathrm{JAK} 2^{\mathrm{V} 617 \mathrm{~F}}$ positive MF $(n$ $=4)$ or CALR positive MF $(n=$ 4) samples were stained with a cIAP1/2 antibody to evaluate expression. cIAP staining was stronger in both $\mathrm{JAK} 2^{\mathrm{V} 617 \mathrm{~F}}$ and CALR positive MF samples compared to the normal controls, particularly in the megakaryocytes (indicated by the black arrows). e

Immunofluorescent images of MF cells $(n=3)$ with ectopic XIAP expression showed reduced cIAP1/2 fluorescence intensity relative to vector control. $* P<0.05$ a

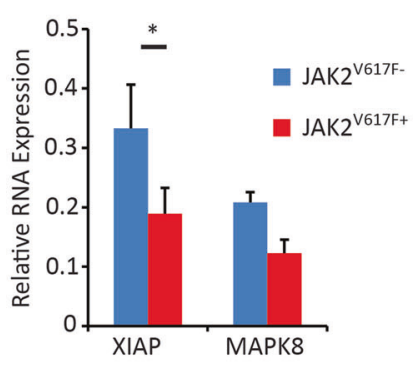

b

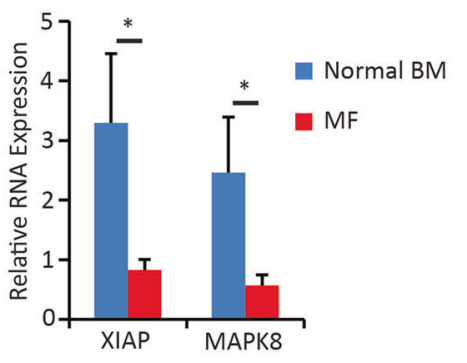

C
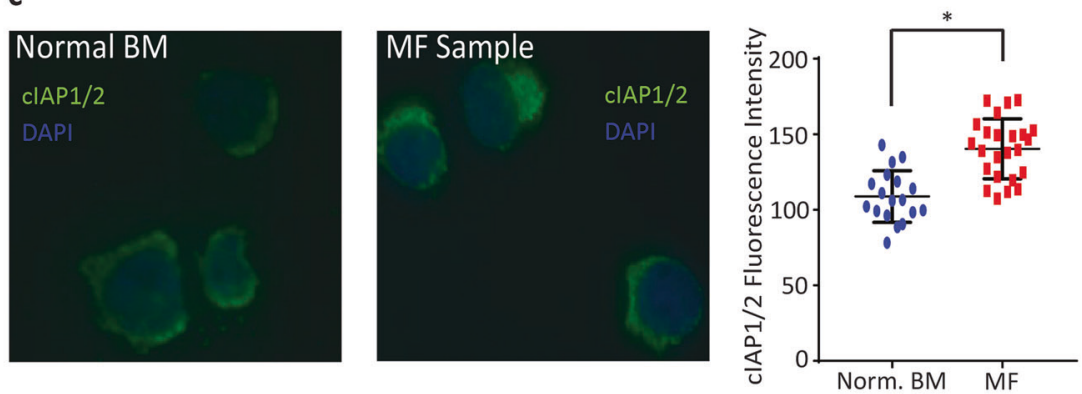

d

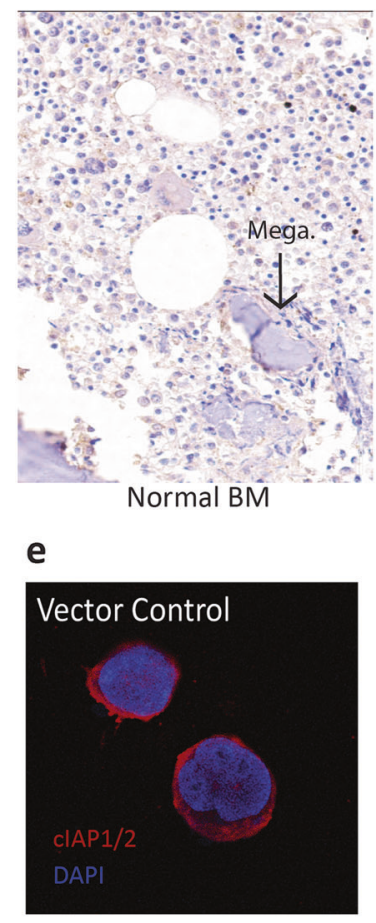

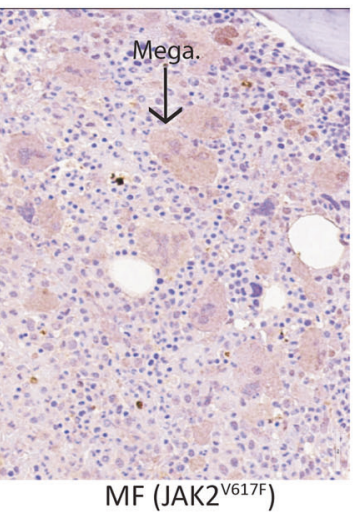

$\mathrm{MF}\left(\mathrm{JAK} 2^{\mathrm{V} 617 \mathrm{~F}}\right)$

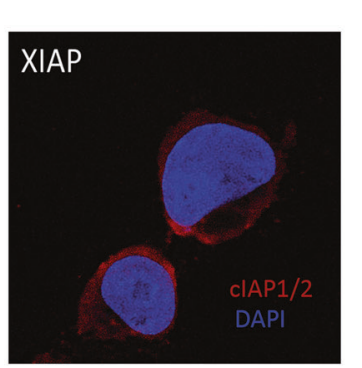

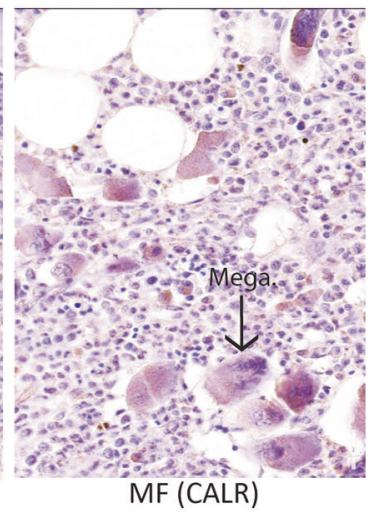

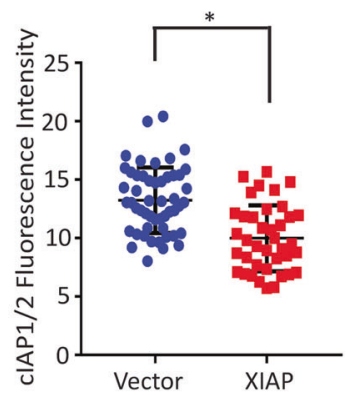

Blocking clAP inhibits survival, while ectopic expression of XIAP or MAPK8 induces apoptosis in primitive MF cells

To test whether cIAP is functionally important, we used birinapant at a concentration that selectively inhibits cIAP over XIAP (10 nM) [37, 38]. CD34 ${ }^{+}$MF and normal BM cells were treated in liquid culture for $72 \mathrm{~h}$ then transferred to semi-solid media. Colony formation was significantly reduced in MF samples relative to normal BM, suggesting that cIAPs favor survival of MPN over normal cells (Fig. 5a). In contrast, $100 \mathrm{nM}$ birinapant inhibited colony growth of $\mathrm{MF}$ and normal BM to a similar degree. Since cIAPs mediate TNF-induced NF- $\mathrm{BB}$ activation [36], we next assessed NF- $\kappa \mathrm{B}$ signaling. MF $(n=3)$ or normal BM $(n=3) \mathrm{CD}_{3} 4^{+}$cells were infected with an $\mathrm{NF}-\kappa \mathrm{B}$ reporter construct, pretreated \pm TNFR1 or TNFR2 BA $(10 \mu \mathrm{g} / \mathrm{mL})$ followed by addition of TNF ( $1 \mathrm{ng} / \mathrm{mL})$. NF- $\kappa$ B activity was 

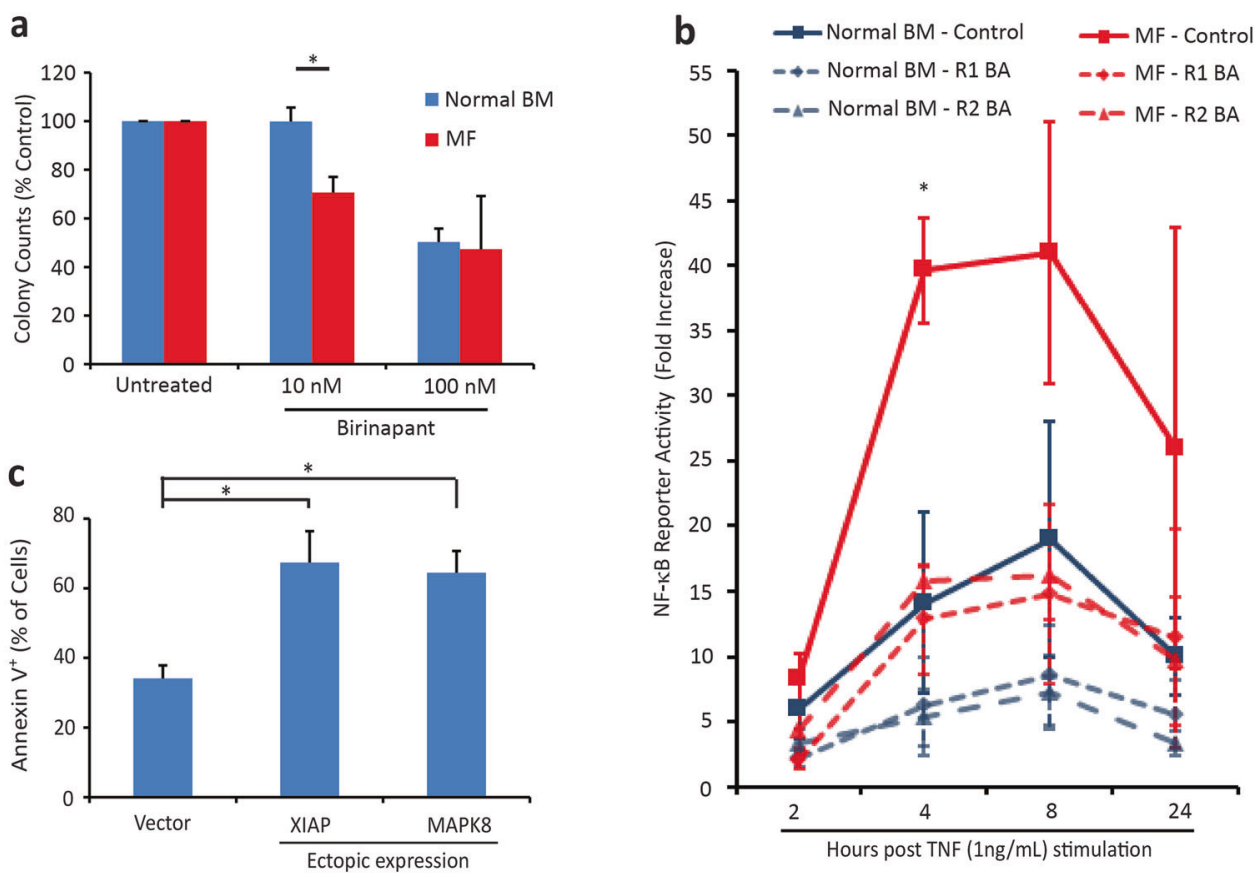

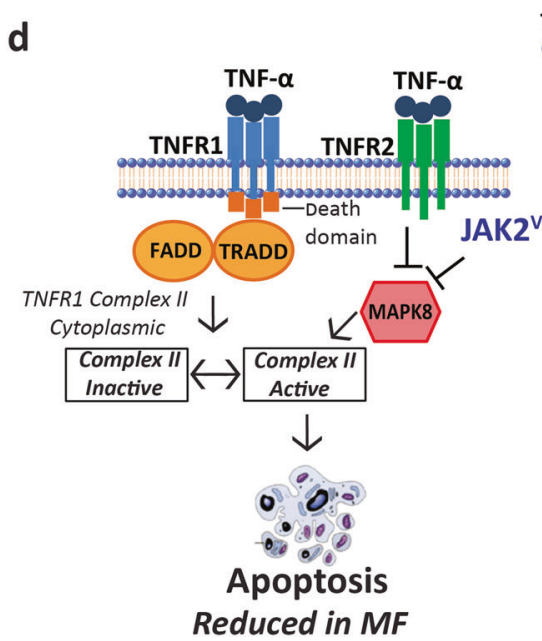

Fig. $5 \mathrm{JAK} 2^{\mathrm{V} 617 \mathrm{~F}}$ and TNFR2 cooperate to increase NF- $\mathrm{KB}$ signaling and reduce apoptosis in MF cells. a Human $\mathrm{CD}_{3} 4^{+}$cells isolated from MF patient $(n=3)$ or normal BM $(n=3)$ were treated with birinapant at 10 or $100 \mathrm{nM}$ for $72 \mathrm{~h}$ in liquid culture and then plated in clonogenic assays with continued treatment. Colony inhibition was significantly different for normal vs. MF samples at $10 \mathrm{nM}$, while $100 \mathrm{nM}$ birinapant inhibited both. b Human $\mathrm{CD} 34^{+}$cells isolated from MF patient $(n=3)$ or normal BM $(n=3)$ were infected with an NF- $\mathrm{KB}$ luciferase reporter construct $72 \mathrm{~h}$ prior to evaluation. Cells were treated with TNFR1 or TNFR2 BA $(10 \mu \mathrm{g} / \mathrm{mL})$ prior to stimulation with TNF (1 $\mathrm{ng} / \mathrm{mL}$ ). The fold increase in reporter activity was significantly higher in MF cells at $4 \mathrm{~h}$ post stimulation and over the complete time course $(P=0.03)$. Both TNFR1 and TNFR2 BAs reduced TNF stimulated

maximal at $8 \mathrm{~h}$ post TNF stimulation with a 41 -fold increase in MF cells and a 19-fold increase in normal BM. NF-kB activity was significantly higher in MF cells over the entire time course $(P=0.03)$. Treatment with either the TNFR1 or

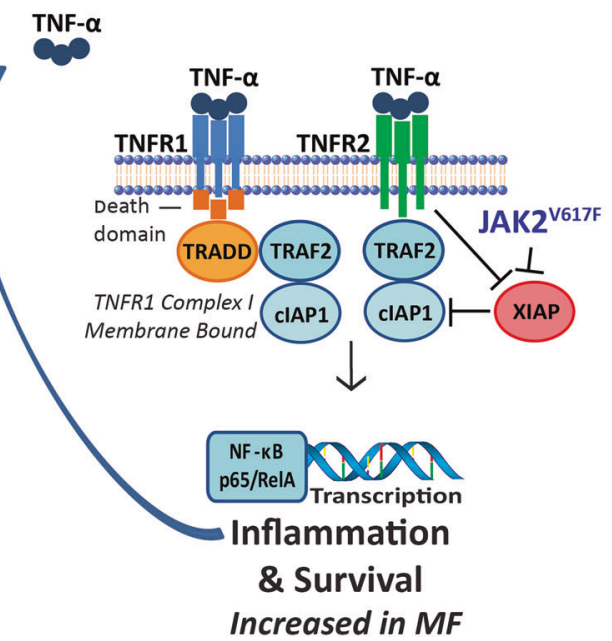

$\mathrm{NF}-\kappa \mathrm{B}$ activity in MF and normal BM cells. c Annexin V was measured in MF CD34 ${ }^{+}$cells $(n=4) 72 \mathrm{~h}$ after infection with XIAP, MAPK8 or vector control expression constructs. Ectopic expression of XIAP or MAPK8 significantly increased Annexin V staining relative to vector control. d Downregulation of MAPK8 by JAK2 $2^{\mathrm{V} 617 \mathrm{~F}}$ and TNFR2 inhibits apoptotic signaling through TNFR1 by preventing MAPK8 from promoting the active form of TNFR1 Complex II. Downregulation of XIAP by JAK2 $2^{\mathrm{V} 617 \mathrm{~F}}$ and TNFR2 is associated with increased cIAP protein levels. Either TNFR1 (with TRADD) or TNFR2 can form a signaling complex through association with TRAF2 and cIAP to activate NF- $\mathrm{KB}$ transcription of pro-survival and inflammation-associated genes. These combined effects favor survival of JAK2 $2^{\mathrm{V} 617 \mathrm{~F}}$ cells. $* P<0.05, * * P<0.005$

TNFR2 BA reduced NF- $\kappa \mathrm{B}$ activity in MF and normal BM cells. Notably, either blocking antibody reduced NF- $\mathrm{KB}$ activity in MF cells to levels seen in the normal BM cells (Fig. 5b). We next ectopically expressed XIAP and/or 
MAPK8 in CD34 ${ }^{+}$cells from MF patient samples $(n=4)$ and measured annexin $\mathrm{V}$ after $72 \mathrm{~h}$. Expression of MAPK8 and XIAP significantly increased annexin $\mathrm{V}^{+}$cells over vector control, suggesting that their downregulation is critical for MPN cells to avoid TNF-induced apoptosis (Fig. 5c).

\section{Discussion}

Chronic low-level inflammation is a feature of the aging hematopoietic system $[9,14,39-43]$. The BM concentrations of key inflammatory cytokines such as TNF and IFN $\gamma$ increase with age and induce a myelomonocytic differentiation bias [9]. Concentrations of inflammatory cytokines are elevated in the plasma of most MPN patients. The highest levels are found in MF and correlate with symptom burden and shorter survival [44]. We have previously shown that TNF mediates the clonal dominance of JAK2 ${ }^{\mathrm{V} 617 \mathrm{~F}}$ over JAK2 ${ }^{\mathrm{WT}}$ cells, implicating TNF as a disease driver [2]. Although many inflammatory cytokines are elevated in MF, these data suggest a central role for TNF in MPN.

We show that TNF expression is higher in most cellular subsets of MF compared to controls under basal conditions, with differences enhanced by LPS in most hematopoietic progenitor cells. This is consistent with recent data showing that different hematopoietic cells have distinct cytokine production profiles including TNF [8]. These results suggest that MPN HSCs express TNF to inhibit the growth of normal HSCs competing for the same niches, especially under systemic inflammatory stress (LPS stimulation). These studies included samples from MF patients with either JAK2 ${ }^{\mathrm{V} 617 \mathrm{~F}}$ or CALR mutations, without appreciable differences between genotypes (patient profiles are provided in Supplemental Table 9).

TNF scavengers, such as etanercept and infliximab are associated with increased risk for opportunistic infections, giving rise to concerns about their use in immunocompromised patients, such as MF [45]. Data on anti-TNF therapeutics in MF are limited to one small study and anecdotal cases $[16,46]$. Consistent with their modest effects in MF patients, etanercept and infliximab failed to reduce MPN disease in mice with JAK2 ${ }^{\mathrm{V} 617 \mathrm{~F}}$ MPN (Supplemental Figure 2). These results are at odds with the attenuation of MPN in a previous study using TNF deficient mice [2] and suggest that additional, unintended effects, of pan-TNF antagonists may neutralize differences in TNF responses between MF and normal cells [2, 47]. Several studies have implicated TNF as a negative regulator of HSCs [48-50]. Conflicting data were reported regarding the requirement for TNFR1 to mediate the suppressive TNF effects on HSCs cultured ex vivo [49, 50]. In competitive repopulation experiments, both $\mathrm{TNFR}^{-1-}$ and $\mathrm{TNFR}^{-/-}$HSCs were shown to outcompete $\mathrm{TNFR}^{\mathrm{WT}}$ cells to a similar degree, with a more pronounced advantage for double null cells [51]. To understand how JAK2 ${ }^{\mathrm{V} 617 \mathrm{~F}}$ reprograms TNF signaling in hematopoietic progenitors from suppression to stimulation, we asked whether this involves altered responses through TNFR1 and/or TNFR2. Our results support a model in which signaling through TNFR2, but not TNFR1, mediates the differential effects of TNF on myeloid colony formation of $\mathrm{JAK} 2^{\mathrm{V} 617 \mathrm{~F}}$ vs. $\mathrm{JAK} 2^{\mathrm{WT}}$ progenitor cells. Although the MF-specific reduction in colony formation with TNFR2 BA or knockdown was relatively modest ( $30 \%$; Fig. $2 a, b, d)$, this difference may be sufficient to promote clonal dominance during the slow evolution of MPN. For unknown reasons, TNFR2 block reduced the $\mathrm{JAK} 2^{\mathrm{V} 617 \mathrm{~F}+}$ colonies much more profoundly in assays of mouse progenitor cells (by $89 \%$, Fig. 2c). It is conceivable that the co-culture of JAK2 $2^{\mathrm{V} 617 \mathrm{~F}}$ and JAK2 ${ }^{\mathrm{WT}}$ cells is necessary to potentiate the differential effect and thus the difference was less dramatic in the human samples where MF and normal cells were cultured individually, in line with the observation that cytokine expression is altered both in mutant and normal cells isolated from MPN mice [8]. It is also possible that the over-expression of JAK2 ${ }^{\mathrm{V} 617 \mathrm{~F}}$ induced by the transduction/transplantation model may have amplified the effect in the mouse cells relative to the human samples. We selected this model because plasma TNF concentrations are elevated over controls to a similar degree as in MF ( 10-15-fold) [26, 47].

The fact that TNFR1 and TNFR2 expression is comparable between MPN and normal BM cells excludes JAK/ STAT regulation of TNFR1/2 expression as the cause of differential TNF responses, instead implicating differences in TNF signaling cascades. We found that expression of Xiap and Mapk8, two regulators of TNF signaling, is reduced in $\mathrm{JAK} 2{ }^{\mathrm{V} 617 \mathrm{~F}+}$ mouse progenitor cells and that blocking TNFR2 restores their expression to the levels in JAK2 ${ }^{\text {WT }}$ cells (Fig. 3a-c). Consistent with the mouse experiments, expression of XIAP and MAPK8 was lower in human MF vs. normal BM CD $34^{+}$cells (Fig. 4b). Reduced expression of Xiap in murine JAK2 $2^{\mathrm{V} 617 \mathrm{~F}+}$ cells could be considered counterintuitive as XIAP inhibits caspases and hence apoptosis [52]. However, there is evidence for mutual regulation between XIAP and cIAP. Thus cIAP expression is increased in Xiap null mice, and this has been linked to the ability of XIAP to promote cIAP ubiquitination and proteasomal degradation, and vice versa [34, 35]. Indeed, cIAP expression was higher in MF compared to normal $\mathrm{CD} 34^{+}$cells and BM biopsies. Attempts to assess XIAP protein levels in hematopoietic cells were unsuccessful, but consistent with above predictions, ectopic expression of XIAP-induced apoptosis in MF $\mathrm{CD} 34^{+}$cells (Fig. 5c). Similarly, in many cancer cell lines, IAP proteins inhibit 
apoptosis induced by TNF [53, 54]. Downregulation of cIAPs or treatment with a cIAP inhibitor allows TNFdependent apoptosis to proceed. This is reminiscent of our findings in MF cells, which are more sensitive than control to inhibition with the IAP inhibitor birinapant, at concentrations that block cIAP, but not XIAP; while the differential is lost at higher concentrations that block both (Fig. 5a). cIAP promotes activation of NF-kB and, as predicted, NF-kB reporter activity was shown to be higher in MF cells relative to normal BM cells (Fig. 5b) as reported by others [55]. This is consistent with data for the cIAP inhibitor LCL161, which is demonstrating activity in early clinical testing for the treatment of MF [56]. A second entry point into TNFR signaling involves reduction of MAPK8 expression to inhibit apoptotic signaling through TNFR1 Complex II. As MAPK8 promotes degradation of c-FLIP $\mathrm{I}_{\mathrm{L}}$ [20], reduced MAPK8 should stabilize the c-FLIP ${ }_{L}$ heterodimer with procaspase-8, favoring the inactive form of TNFR1 Complex II (Fig. 5d).

Altogether our findings are consistent with a model, in which MF cells downregulate XIAP and MAPK8 through a TNF/TNFR2-dependent autocrine loop to escape an apoptotic response and enhance $\mathrm{NF}-\kappa \mathrm{B}$ signaling (Fig. 5d). Since $\mathrm{NF}-\kappa \mathrm{B}$ is also a key mediator of inflammatory cytokine expression [57], this creates a positive feedback loop where TNF functions as a master regulator of inflammatory cytokine production in MPN cells. Studies to determine exactly how JAK $2^{\mathrm{V} 617 \mathrm{~F}}$ and other MF-associated mutations modulate TNFR2 signaling to limit the expression of XIAP and MAPK8 compared to their normal competitors are in progress. Our work supports the further clinical development of cIAP inhibitors and implicates selective TNFR2 inhibitors as potential therapeutics in the treatment of MF.

Acknowledgements This work was supported by a Leukemia \& Lymphoma Society (LLS) Translational Research Program Award (6086-12) (MWD). We thank James Marvin, director of the Flow Cytometry Core Facility, at the University of Utah for his assistance with experimental design. We also thank Kim Reynolds and Mariko Sato for their technical assistance on the project.

Funding CNTO5048 and CNTO6601 were both kindly provided by Janssen Research \& Development (Radnor, PA).

Authors contributions: WLH designed experiments, carried out experiments, analyzed the data and wrote the manuscript; AVS carried out animal experiments, ADP designed experiments and analyzed the data; MES carried out experiments and analyzed the data; PMC processed patient samples; DY carried out experiments; RNB analyzed the microarray data; JMG and JTP provided BM and blood samples; TO reviewed the manuscript and provided critical feedback; MWD designed experiments and wrote the manuscript.

\section{Compliance with ethical standards}

Conflict of interest MWD is on the advisory board and is a consultant for Incyte, Novartis, and Pfizer, and serves on the advisory board for
Ariad, Blueprint, and Galena BioPharma. His laboratory receives research funding from Novartis and Pfizer.

Open Access This article is licensed under a Creative Commons Attribution 4.0 International License, which permits use, sharing, adaptation, distribution and reproduction in any medium or format, as long as you give appropriate credit to the original author(s) and the source, provide a link to the Creative Commons license, and indicate if changes were made. The images or other third party material in this article are included in the article's Creative Commons license, unless indicated otherwise in a credit line to the material. If material is not included in the article's Creative Commons license and your intended use is not permitted by statutory regulation or exceeds the permitted use, you will need to obtain permission directly from the copyright holder. To view a copy of this license, visit http://creativecommons. org/licenses/by/4.0/.

\section{References}

1. Rampal R, Al-Shahrour F, Abdel-Wahab O, Patel JP, Brunel J-P, Mermel $\mathrm{CH}$, et al. Integrated genomic analysis illustrates the central role of JAK-STAT pathway activation in myeloproliferative neoplasm pathogenesis. Blood. 2014;123:e123-e133.

2. Fleischman AG, Aichberger KJ, Luty SB, Bumm TG, Petersen CL, Doratotaj S, et al. TNFalpha facilitates clonal expansion of JAK2V617F positive cells in myeloproliferative neoplasms. Blood. 2011;118:6392-8.

3. James C, Ugo V, Le Couedic J-P, Staerk J, Delhommeau F, Lacout $\mathrm{C}$, et al. A unique clonal JAK2 mutation leading to constitutive signalling causes polycythaemia vera. Nature. 2005;434:1144-8.

4. Pikman Y, Lee BH, Mercher T, McDowell E, Ebert BL, Gozo M, et al. MPLW515L is a novel somatic activating mutation in myelofibrosis with myeloid metaplasia. PLoS Med. 2006;3:e270.

5. Nangalia J, Massie CE, Baxter EJ, Nice FL, Gundem G, Wedge DC, et al. Somatic CALR mutations in myeloproliferative neoplasms with nonmutated JAK2. New Engl J Med. 2013;369:2391-405.

6. Klampfl T, Gisslinger H, Harutyunyan AS, Nivarthi H, Rumi E, Milosevic JD, et al. Somatic mutations of calreticulin in myeloproliferative neoplasms. New Engl J Med. 2013;369:2379-90.

7. Verstovsek S. Ruxolitinib for myelofibrosis: from "palliation" to prolongation of survival. Oncology. 2013;27:717-8.

8. Kleppe M, Kwak M, Koppikar P, Riester M, Keller M, Bastian L, et al. JAK-STAT pathway activation in malignant and nonmalignant cells contributes to MPN pathogenesis and therapeutic response. Cancer Discov. 2015;5:316-31.

9. Kovtonyuk LV, Fritsch K, Feng X, Manz MG, Takizawa H. Inflamm-aging of hematopoiesis, hematopoietic stem cells, and the bone marrow microenvironment. Front Immunol. 2016;7:502.

10. Xie M, Lu C, Wang J, McLellan MD, Johnson KJ, Wendl MC, et al. Age-related cancer mutations associated with clonal hematopoietic expansion. Nat Med. 2014;20:1472-8.

11. Genovese G, Kähler AK, Handsaker RE, Lindberg J, Rose SA, Bakhoum SF, et al. Clonal hematopoiesis and blood-cancer risk inferred from blood DNA sequence. New Engl J Med. 2014;371:2477-87.

12. Jaiswal S, Fontanillas P, Flannick J, Manning A, Grauman PV, Mar BG, et al. Age-related clonal hematopoiesis associated with adverse outcomes. New Engl J Med. 2014;371:2488-2498.

13. McKerrell T, Park N, Moreno T, Grove Carolyn S, Ponstingl H, Stephens $\mathrm{J}$, et al. Leukemia-associated somatic mutations drive distinct patterns of age-related clonal hemopoiesis. Cell Rep. 2015;10:1239-45. 
14. Pang WW, Price EA, Sahoo D, Beerman I, Maloney WJ, Rossi DJ, et al. Human bone marrow hematopoietic stem cells are increased in frequency and myeloid-biased with age. Proc Natl Acad Sci USA. 2011;108:20012-7.

15. Price GL, Davis KL, Karve S, Pohl G, Walgren RA. Survival patterns in United States (US) medicare enrollees with non-CML myeloproliferative neoplasms (MPN). PLoS ONE. 2014;9:e90299.

16. Steensma DP, Mesa RA, Li CY, Gray L, Tefferi A. Etanercept, a soluble tumor necrosis factor receptor, palliates constitutional symptoms in patients with myelofibrosis with myeloid metaplasia: results of a pilot study. Blood. 2002;99:2252-4.

17. Bremer E. Targeting of the tumor necrosis factor receptor superfamily for cancer immunotherapy. ISRN Oncol. 2013;2013:25.

18. Micheau O, Tschopp J. Induction of TNF receptor I-mediated apoptosis via two sequential signaling complexes. Cell. 2003;114:181-90.

19. Irmler M, Thome M, Hahne M, Schneider P, Hofmann K, Steiner $\mathrm{V}$, et al. Inhibition of death receptor signals by cellular FLIP. Nature. 1997;388:190-5.

20. Chang L, Kamata H, Solinas G, Luo JL, Maeda S, Venuprasad K, et al. The E3 ubiquitin ligase itch couples JNK activation to TNFalpha-induced cell death by inducing c-FLIP(L) turnover. Cell. 2006;124:601-13.

21. Rodriguez M, Cabal-Hierro L, Carcedo MT, Iglesias JM, Artime $\mathrm{N}$, Darnay BG, et al. NF-kappaB signal triggering and termination by tumor necrosis factor receptor 2. J Biol Chem. 2011;286:22814-24.

22. Majeti R, Park CY, Weissman IL. Identification of a hierarchy of multipotent hematopoietic progenitors in human cord blood. Cell Stem Cell. 2007;1:635-45.

23. Challen GA, Boles N, Lin KK, Goodell MA. Mouse hematopoietic stem cell identification and analysis. Cytometry A. 2009;75:14-24.

24. Jung T, Schauer U, Heusser C, Neumann C, Rieger C. Detection of intracellular cytokines by flow cytometry. J Immunol Methods. 1993;159:197-207.

25. Schauer U, Jung T, Krug N, Frew A. Measurement of intracellular cytokines. Immunol Today. 1996;17:305-6.

26. Bumm TG, Elsea C, Corbin AS, Loriaux M, Sherbenou D, Wood $\mathrm{L}$, et al. Characterization of murine JAK2V617F-positive myeloproliferative disease. Cancer Res. 2006;66:11156-65.

27. Tyner JW, Bumm TG, Deininger J, Wood L, Aichberger KJ, Loriaux MM, et al. CYT387, a novel JAK2 inhibitor, induces hematologic responses and normalizes inflammatory cytokines in murine myeloproliferative neoplasms. Blood. 2010;115:5232-40.

28. Rose S, Eren M, Murphy S, Zhang H, Thaxton CS, Chowaniec J, et al. A novel mouse model that develops spontaneous arthritis and is predisposed towards atherosclerosis. Ann Rheum Dis. 2013;72:89-95.

29. Lei B, Dawson HN, Roulhac-Wilson B, Wang H, Laskowitz DT, James ML. Tumor necrosis factor alpha antagonism improves neurological recovery in murine intracerebral hemorrhage. J Neuroinflamm. 2013;10:103.

30. Holdsworth SR, Gan P-Y, Kitching AR. Biologics for the treatment of autoimmune renal diseases. Nat Rev Nephrol. 2016;12:217-31.

31. Shiau MY, Chiou HL, Lee YL, Kuo TM, Chang YH. Establishment of a consistent L929 bioassay system for TNF-alpha quantitation to evaluate the effect of lipopolysaccharide, phytomitogens and cytodifferentiation agents on cytotoxicity of TNF-alpha secreted by adherent human mononuclear cells. Mediat Inflamm. 2001;10:199-208.

32. Shealy DJ, Wooley PH, Emmell E, Volk A, Rosenberg A, Treacy $\mathrm{G}$, et al. Anti-TNF- $\alpha$ antibody allows healing of joint damage in polyarthritic transgenic mice. Arthritis Res. 2002;4:R7-R7.
33. Deng Y, Ren X, Yang L, Lin Y, Wu X. A JNK-dependent pathway is required for TNFo-induced apoptosis. Cell. 2003;115:61-70.

34. Silke J, Kratina T, Chu D, Ekert PG, Day CL, Pakusch M, et al. Determination of cell survival by RING-mediated regulation of inhibitor of apoptosis (IAP) protein abundance. Proc Natl Acad Sci USA. 2005;102:16182-7.

35. Harlin H, Reffey SB, Duckett CS, Lindsten T, Thompson CB. Characterization of XIAP-deficient mice. Mol Cell Biol. 2001;21:3604-8.

36. Mahoney DJ, Cheung HH, Mrad RL, Plenchette S, Simard C, Enwere E, et al. Both cIAP1 and cIAP2 regulate TNF $\alpha$-mediated NF-KB activation. Proc Natl Acad Sci USA. 2008;105:11778-83.

37. Benetatos CA, Mitsuuchi Y, Burns JM, Neiman EM, Condon SM, Yu G, et al. Birinapant (TL32711), a bivalent SMAC mimetic, targets tRAF2-associated cIAPs, abrogates TNF-induced NF-кB activation, and is active in patient-derived xenograft models. Mol Cancer Ther. 2014;13:867-79.

38. Allensworth JL, Sauer SJ, Lyerly HK, Morse MA, Devi GR. Smac mimetic Birinapant induces apoptosis and enhances TRAIL potency in inflammatory breast cancer cells in an IAP-dependent and TNF- $\alpha$-independent mechanism. Breast Cancer Res Treat. 2013;137:359-71.

39. Franceschi C, Campisi J. Chronic inflammation (inflammaging) and its potential contribution to age-associated diseases. J Gerontol A. 2014;69(Suppl 1):S4-9.

40. Cho RH, Sieburg HB, Muller-Sieburg CE. A new mechanism for the aging of hematopoietic stem cells: aging changes the clonal composition of the stem cell compartment but not individual stem cells. Blood. 2008;111:5553-61.

41. Beerman I, Bhattacharya D, Zandi S, Sigvardsson M, Weissman IL, Bryder D, et al. Functionally distinct hematopoietic stem cells modulate hematopoietic lineage potential during aging by a mechanism of clonal expansion. Proc Natl Acad Sci USA. 2010;107:5465-70.

42. Chambers SM, Shaw CA, Gatza C, Fisk CJ, Donehower LA, Goodell MA. Aging hematopoietic stem cells decline in function and exhibit epigenetic dysregulation. PLoS Biol. 2007;5:e201.

43. King KY, Goodell MA. Inflammatory modulation of HSCs: viewing the HSC as a foundation for the immune response. Nat Rev Immunol. 2011;11:685-92.

44. Geyer HL, Dueck AC, Scherber RM, Mesa RA. Impact of inflammation on myeloproliferative neoplasm symptom development. Mediat Inflamm. 2015;2015:284706.

45. Cantini F, Niccoli L, Goletti D. Adalimumab, etanercept, infliximab, and the risk of tuberculosis: data from clinical trials, national registries, and postmarketing surveillance. J Rheumatol Suppl. 2014;91:47-55.

46. Ong A, Quach H, Leech M. Reversal of transfusion dependence by tumor necrosis factor inhibitor treatment in a patient with concurrent rheumatoid arthritis and primary myelofibrosis. J Clin Rheumatol. 2011;17:211-3.

47. Sollazzo D, Forte D, Polverelli N, Romano M, Perricone M, Rossi $\mathrm{L}$, et al. Crucial factors of the inflammatory microenvironment (IL-1beta/TNF-alpha/TIMP-1) promote the maintenance of the malignant hemopoietic clone of myelofibrosis: an in vitro study. Oncotarget. 2016;7:43974-88.

48. Bryder D, Ramsfjell V, Dybedal I, Theilgaard-Monch K, Hogerkorp CM, Adolfsson J, et al. Self-renewal of multipotent longterm repopulating hematopoietic stem cells is negatively regulated by Fas and tumor necrosis factor receptor activation. J Exp Med. 2001;194:941-52.

49. Dybedal I, Bryder D, Fossum A, Rusten LS, Jacobsen SE. Tumor necrosis factor (TNF)-mediated activation of the p55 TNF receptor negatively regulates maintenance of cycling reconstituting human hematopoietic stem cells. Blood. 2001;98:1782-91. 
50. Drutskaya MS, Kuprash DV, Nedospasov SA, Chertkov IL, Drize NI. Abnormal hemopoiesis in long-term bone marrow culture from tumor necrosis factor-deficient mice. Bull Exp Biol Med. 2001;131:150-2.

51. Pronk CJ, Veiby OP, Bryder D, Jacobsen SE. Tumor necrosis factor restricts hematopoietic stem cell activity in mice: involvement of two distinct receptors. $J$ Exp Med. 2011;208:1563-70

52. Wong WW, Vince JE, Lalaoui N, Lawlor KE, Chau D, Bankovacki A, et al. cIAPs and XIAP regulate myelopoiesis through cytokine production in an RIPK1- and RIPK3-dependent manner. Blood. 2014;123:2562-72.

53. Vince JE, Wong WW, Khan N, Feltham R, Chau D, Ahmed AU, et al. IAP antagonists target cIAP1 to induce TNFalpha-dependent apoptosis. Cell. 2007;131:682-93.
54. Petersen SL, Wang L, Yalcin-Chin A, Li L, Peyton M, Minna J, et al. Autocrine TNFalpha signaling renders human cancer cells susceptible to Smac-mimetic-induced apoptosis. Cancer Cell. 2007;12:445-56.

55. Kleppe M, Koche R, Zou L, van Galen P, Hill CE, Dong L, et al. Dual Targeting of Oncogenic Activation and Inflammatory Signaling Increases Therapeutic Efficacy in Myeloproliferative Neoplasms. Cancer Cell. 2018;33:29-43.e27.

56. Pemmaraju N, Carter BZ, Kantarjian HM, Cortes JE, Kadia TM, Garcia-Manero G, et al. Results for phase II clinical trial of LCL161, a SMAC mimetic, in patients with primary myelofibrosis (PMF), postpolycythemia vera myelofibrosis (post-PV MF) or post-essential thrombocytosis myelofibrosis (post-ET MF). Blood. 2016;128:3105.

57. Hoesel B, Schmid JA. The complexity of NF- $\kappa \mathrm{B}$ signaling in inflammation and cancer. Mol Cancer. 2013;12:86-86. 